\section{Serum Alkaline Phosphatase}

Urthophosphoric monoester phosphohydrolase, better known as alkaline phosphatase, can normally be detected in serum and in extracts prepared from many different tissues, notably bone, liver, intestine, kidney, and placenta. In adults serum alkaline phosphatase is predominantly of hepatic origin; a small but variable amount of the intestinal isoenzyme can also be demonstrated. ${ }^{12}$ Earlier work ${ }^{3}$ suggesting that the enzyme in serum came predominantly from bone has been discounted in view of the lack of specificity of the antisera for individual tissue phosphatases, ${ }^{4}$ but the isoenzyme from bone is normally present in sera from children, and its presence accounts for the higher total activities that are observed up to puberty. In the investigation of liver disease in children measurements of the more specific 5'-ribonucleotide phosphohydrolase (5-nucleotidase) are preferable, since this enzyme is predominantly of hepatic origin and its normal range of activity in serum does not show variation with age. ${ }^{5}$ Elevation of the serum alkaline phosphatase due to the placental isoenzyme reverts to normal within a few days of the end of pregnancy. ${ }^{6}$

There are two important causes for raised serum alkaline phosphatase activity: those diseases of bone in which there is increased osteoblastic activity, and disease of the liver, especially where there is obstruction to the outflow of bile, either intrahepatic or extrahepatic. Controversy existed for many years over the source of the raised serum alkaline phosphatase in these two categories of disease until D. W. Moss

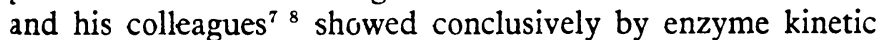
studies that the alkaline phosphatase in serum collected from patients with disease of bone had kinetic properties which distinguished it from that found in patients with liver disease. This has been confirmed independently by electrophoresis. ${ }^{129}$ For 30 years the tendency to link alkaline phosphatase with bone had led to the assumption that the liver acted as an excretory organ for the enzyme released from bone and that elevated alkaline phosphatase in the serum of patients with liver disease or obstruction to the outflow of bile was due to retention of the enzyme. ${ }^{10} \mathrm{~A}$ number of recent reports have supported the alternative theory of overproduction of alkaline phosphatase by the liver in these cases. The evidence includes the finding that the main components of alkaline phosphatase normally present in serum and bile are different ${ }^{11-13}$; that

\footnotetext{
' Hodson, A. W., Latner, A. L., and Raine, L., Clin. chim. Acta, 1962, 7, 255.

Kreisher, J. H., Close, V. A., and Fishman, W. H., Clin. chim. Acta, 1965, 11, 122 .

- Schlamowitz, M., and Bodansky, O., f. biol. Chem., 1959, 234, 1433.

- Boyer, S. H., Ann. N.Y. Acad. Sci., 1963, 103, 938.

Young, I. I., Ann. N.Y. Acad. Sci., 1958, 75, 357.

McMaster, Y., Tennant, R., Clubb, J. S., Neale, F. C., and Posen, S., 7. Obstet. Gynaec Brit. Covlth, 1964, 71, 735 .

Moss, D. W., Campbell, D. M., Anagnostou-Kakaras, E., and King, M. J., Biochem. F., 1961, 81, 441.

Moss D. W., Campbell, D. M., Anagnostou-Kakaras, E., and King, E. J., Pure appl. Chem., 1961, 3, 397.

Arfors, K. E., Beckman, L., and Lundin, L. G., Acta genet. (Basel), $1963,13,89$

- Gutman, A. B., Amer. F. Med., 1959, 27, 875

1 Keiding, N. R., Clin. Sci., 1964, 26, 291.

2 Pope, C. E., and Cooperband, S. R., Gastroenterology, 1966, 50, 631

"Hill, P. G., and Sammons, H. G., f. clin. Path., 1967, 20, 654.

- Sebesta, D. G., Bradshaw, F. J., and Prockop, D. J., Gastroenterology, $1964,47,166$.

16 Polin, S. G., Spellberg, M. A., Teitelman, L., and Okumuoro, J., Gastroenterology, 1962, 42, 431 .

16 Allen, H., and Spellberg, M. A., Arch. intern. Med., 1967, 120, 667

17 Roberts, W. M., Brit. med. F., 1933, 1, 734.

Moss, D. W., Proc. Ass. clin. Biochem., 1964, 3, 132.

Amador, E., Zimmerman, T. S., and Wacker, W. E. C., f. Amer. med. Ass., 1963, 185, 769 .

10 Butterworth, P. J., Moss, D. W., Pitkanen, E., and Pringle, A., Clin chim. Acta, 1965, 11, $212 ; 220$.

${ }^{2}$ Hill, P. G., and Sammons, H. G., Ouart. F. Med., 1967, 36, 457.

2 Maclagan, N. F., Proc. roy. Soc. Med., 1961, 54, 121.
}

perfusion of the liver in cats leads to large increases in the alkaline phosphatase activity in the perfusate, but only when the biliary system is obstructed ${ }^{14}$; and that in dogs ligation of the hepatic duct draining one lobe of the liver causes an increase in the alkaline phosphatase activity in serum and bile and in the lobe drained by the ligated duct. ${ }^{15}$ Investigations on patients with hepatobiliary disease have also been interpreted as favouring the hepatic origin of increased alkaline phosphatase. ${ }^{13} 16$

An alkaline phosphatase can be detected in urine, but this does not represent a major route of excretion in man, ${ }^{17}$ though increased excretion of alkaline phosphatase in urine has been reported in some patients with jaundice and a high serum alkaline phosphatase. ${ }^{1618}$ The alkaline phosphatase found in normal urine has electrophoretic and chromatographic properties which distinguish it from serum and from tissue phosphatases. In the presence of disease of the renal tract. however, the level of alkaline phosphatase can be readily shown to be raised if steps are taken to remove inhibitors present in urine before measuring the enzymatic activity. ${ }^{16} 1920$

Serum alkaline phosphatase measurements have an established place in the investigation of suspected diseases of bone, and they are still widely used in the investigation of liver diseases, though 5-nucleotidase has been advocated as an alternative for this latter purpose. ${ }^{21}$ In common with othes "liver-function tests" it is important that the first measurement of alkaline phosphatase is made as early as possible in the course of the illness, before complications set in. With a baseline series of observations changes occurring later during the disease are less confusing to interpret. The value of estimations of the serum alkaline phosphatase in the investigation of jaundice is improved if the results are interpreted in combination with other tests of liver function, ${ }^{22}$ but no combination of biochemical tests can by themselves at present differentiate between intrahepatic and extrahepatic causes of obstruction, and a comprehensive assessment of the patient's illness must be made.

\section{Festschrift for McMichael}

As professor of medicine at Hammersmith for twenty yeas until he retired in 1966, Sir John McMichael, F.R.S., did as much as anyone to give the Royal Postgraduate Medical School its unique reputation for excellence. To the hosts of students who came there from all over the world he seemed to embody all the physicianly virtues. Anyone fortunate enough to have seen $\mathrm{McMichael}$ in action at a clinico pathological conference will know him also as an inspiring teacher, alert always in his search for the truth to encourage the most junior of his colleagues. Now director of the British Postgraduate Medical Federation, he can continue to exercise his beneficent influence on postgraduate education as well as retain old links with the school. The variety of these is evident from the Festschrift published in his honour as a special issue of the Postgraduate Medical fournal.' The range of subjects on which some of his old colleagues and students contribute articles reflect his own wide interestsdiseases of the cardiovascular system, the kidneys, and the liver to name a few. A bibliography of his own papers concludes the journal. This is a stimulating tribute to one who is himself renowned for the stimulus he imparted over the years to so many medical men and women.

Postgrad. med. F., 1968, 44, 1-126. 